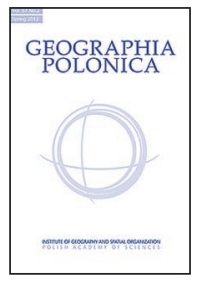

\title{
CHALLENGES AND OPPORTUNITIES FOR HUMAN GEOGRAPHY: A FEW REMARKS ${ }^{\star}$
}

\author{
Vladimír Ira ${ }^{1,2}$ (D) René Matlovič ${ }^{1}$ (D) \\ ${ }^{1}$ Institute of Geography \\ Slovak Academy of Sciences \\ Štefánikova 49, 81473 Bratislava: Slovakia \\ e-mails: geogira@savba.sk・geogmat|@savba.sk \\ ${ }^{2}$ Department of Geography, Faculty of Education \\ University of South Bohemia in České Budějovice \\ Jeronýmova 10, 37115 České Budějovice: Czechia \\ e-mail: vira@pf.jcu.cz
}

\begin{abstract}
In the long-term development of human geography we can observe a tendency to combine ideas from an intradisciplinary debate and those imported from outside the discipline. It is profoundly influenced by a number of impulses from the rapidly changing world. This paper provides a brief survey of challenges for human geography setting them within the context of paradigmatic development and economic, social, cultural, environmental, political, and technological changes. It briefly focuses on the debates of human geographers what their discipline could or should study in the near future and how it could be done. Part of the paper is devoted to a few reflections of authors from the Visegrad Four countries concentrating attention to further direction of human geography. Human geography is unlikely to be characterised by a mono-paradigm dominance in the next few decades, but a discussion on how to find a common base for the integration of paradigms in geography is likely to continue. Changing hierarchical structures, significant modernization processes, as well as local, regional and global changes influencing space-time behavioural patterns of humans can be expected among the main sources of inspiration for the human geographic research.
\end{abstract}

\section{Key words}

human geography $\cdot$ challenges - future directions - geographical thought $\bullet$ integration of paradigms • Visegrad Four countries

\section{Introduction}

The contemporary world faces many challenges. It is characterized by the increasing complexity, connectivity and fluidity. Traditional demarcations are blurred. We have been witnessing many ambivalent tendencies. The acceleration of technological progress

* This article is a modified version of the Polish text, which appeared in Przegląd Geograficzny (Ira \& Matlovič, 2019). 
tends to the emergence of the evolutionary successor of today's man. Human geography, as a scientific discipline with an ambition to contribute to understanding the current evolution of the world, will have to reflect these facts.

A combination of internalist and externalist approaches can be applied in assessing the greatest challenges that will determine the evolution of human geography in the coming decades (Maddrell, 2009). The first approach emphasizes the internal aspects of scientific research and focuses on exploring paradigms, ideas, concepts, methodological procedures and rules for validating the results of scientific research. It therefore responds to the challenges reflecting on the internal needs of the development of scientific discipline. The second approach accentuates the influence of external factors (natural, environmental, social, economic, cultural, political, and technological), thus considering science a part of social life (Špelda, 2009). In this sense, the condition of maintaining the vitality of scientific discipline is to be able to demonstrate social relevance in the context of its heuristic, application, educational, and moral dimensions (Matlovič \& Matlovičová, 2012 and 2015).

Starting from the outlined conceptual framework, we will discuss the challenges facing human geography on two levels: the reflection level of internal challenges and the reflection level of external challenges. This categorization has a dichotomous tinge, but at this point we emphasize that in fact, there is interference from the stimuli of internal and external provenance. Part of the paper will be devoted to some reflections of authors from the Visegrad Four countries concentraiting attention to directions of human geographic research.

\section{Challenges affected by the internal development of human geography}

The greatest challenge not only for human geography, but also for geography as such will be to preserve its disciplinary integrity, identity and autonomy. Geography has been struggling with this problem since its academic institutionalization (Matlovič, Matlovičová, \& Nemethyová, 2012). Geography is one of the sciences with open and permeable boundaries in relation to other scientific disciplines and its position is at the intersection of the defined categories within different science classification systems. Geography's mission is to synthesize efforts to converge or bridge science, social science and humanities. Geography has the ambition to elucidate the mechanisms and effects of interdependent natural, technical and social processes structuring space-time, as well as to understand the nature of the identity and individuality of places at different taxonomic (scale) levels of a local-global continuum (Matlovič \& Matlovičová, 2015).

This mission represents an extremely complicated challenge, as there are ambivalent integration-disintegration tendencies within geography. The integration tendency is related to the effort of geography to authentically fulfil its mission of a synthesizing discipline. It is represented by the search for an integration platform, dimming concepts or themes. The disintegration tendency reflects on the ontological and epistemological context. The ontological context is represented by the hybrid nature of the geography research object, consisting of both material and intangible geospheres of inorganic, organic and anthropogenic nature. As a result, the specialization of geographic research is deepening, resulting in a number of partial subdisciplines (Matlovič, 2006 and 2007). The epistemological context is represented by a plurality of exploratory views that seek to grasp the complex and hybrid reality, which has led to the creation of the multi-paradigmatic nature of geography (Graves, 1981). Each paradigm makes it possible to explore and analyze only a limited range of phenomena, or a limited set of aspects of reality at the expense of others that it ignores (Drulák, 2009).

However, the plurality of paradigms raises the problem of the comparability of the exploratory views that are applied in geography. 
This is because the humanistic methodological model is infiltrated with values, which makes it impossible to apply the principle of neutrality and objectivity of the researcher who is backed by proponents of nomothetic geography tending to neopositivism, analytic philosophy and philosophy of science. They promote methodological unification of geography based on a naturalistic methodological model. On the other hand, geographers inspired by anti-positivist philosophies reject the unrealistic demands for the neutrality and objectivity of the researcher and point to the fundamental limitations of naturalistic methodology. Thus, geography, especially human geography, is represented by coexisting and often competing paradigmatic communities. Their members share a conceptual or taxonomic structure (lexical taxonomy) that keeps their scientific community together while isolating it from other communities of paradigmatic nature (Kuhn, 1997). In this context, the metageographic discourse in the late 1980s introduced a plurality of 'geographies' instead of the singular 'geography', arguing that capturing the complexity of the world under study requires many geographies (Hubbard, Kitchin, Bartley, \& Fuller, 2002). This strategy brings certain risks because it significantly reinforces the disintegration tendencies within the discipline, which in extreme cases may result in its dissolution.

The present multiparadigmatic character of human geography is represented by several paradigms with different lengths of their own tradition. Since the 1950s, the spatial science paradigm has been developing. Its origin is situated within a framework of modern positivist geography (Matlovič \& Matlovičová, 2015). In the 1970s, this paradigm was subjected to overwhelming criticism, which came from two directions - from humanistic and structuralist (critical) geography. Nevertheless, it has maintained its paradigmatic community, while in recent decades we can observe a revival of interest in spatial science. This concern is related to the wider use of the GIS and the progressive overcoming of dichotomy between quantitative and qualitative approaches, and the need to use statistical methods in critical geography as well (Nayak \& Jeffrey, 2011). New impulses were brought by the "big data" phenomenon connected with a revolution in social media and mobile information and communication technologies. According to Mayer-Schönberger and Cukier (2014), this process can be called datafication, i.e. the collection of information about everything that is happening in the world. These data represent a great opportunity for the use in geographic research. At the same time, however, they represent a huge challenge with regard to their methods of processing and the ethics of research.

The complexity and comprehensiveness of reality examined by geography and the pursuit of its fullest knowledge raises the question of the compatibility of the different paradigmatic perspectives, because this effort requires their interconnection (combination), which results from the idea of paradigmatic complementarism. The challenge for (human) geography is therefore to find a diminishing epistemology in which several scientific optics could be productively combined. The main task is to deal with the problem of the commensurability of paradigms. Paradigmatic complementarism is a compromise position between the incommensurability of paradigms (preferring logical coherence - consistency) on the one hand and eclecticism (maximizing empirical coverage) on the other. While paradigmatic complementarism threatens only the identity of individual paradigms, eclecticism also leads to a loss of internal coherence of the resulting research (Drulák, 2009).

Thus, the merging of paradigmatic perspectives should be non-eclectic. It requires a consistent reflection of the metatheoretical assumptions of the theories and concepts we work with and want to combine. The challenge in this case is to find a common base or metatheoretic framework that will allow the various paradigms to be integrated into one whole. There are several possibilities for the philosophical anchoring of this common base. The positivist, scientific-realistic 
and instrumentalist (pragmatic) frameworks appear most often in discourse (Drulák, 2009). The positivist framework is essentialist, based on a coherence theory of truth (truthfulness is defined by the logical consistency). It understands causality in a very restrictive way according to the deductivenomological model (subordination of the event under universal law) and excludes noncausal research from the science regime. For these reasons, it is practically impossible to combine it with the constructivist frameworks. The other two frameworks are constructivist. The scientific-realistic framework relies on the correspondence theory of truth (defines truth by consistency with objective reality). The instrumentalist framework is based on a pragmatic and consensual theory of truth (they define truthfulness by being useful for solving a given problem or by the consensus of the leading representatives of the scientific community). As a basis for the synthesis, it advocates concepts but not theories or paradigms, because it provides greater flexibility. These two frameworks maintain a distance from radical scepticism and relativism, which, in the absence of an unshakable foundation, deduce that truth cannot be distinguished from untruth and that various statements are incommensurable (Drulák, 2009). The discussion on how to find a common base for the integration of paradigms in geography is likely to continue and then it will be obvious whether scientific realism or instrumentalism will prevail or whether other possibilities will emerge.

\section{Challenges affected by the external environment}

Challenges from the external environment can be categorized according to their origin - environmental, economic, social, cultural, political, and technological.

A very important challenge is the impact of human activities on the planetary ecosystem of the Earth. This topic has been at the heart of geography since its very beginnings in antiquity (the so-called man-land tradition - Pattison, 1964). The unprecedented dynamism and global impact of this activity has stimulated scientists to conceptualize a new geological epoch called Anthropocene (Crutzen \& Stoermer, 2000). The current discussion focused on understanding and explaining global environmental change, places a much larger emphasis on the theme of change in general, particularly transformational social change. There also calls for critical reflection on the types of changes that are being promoted. K. O'Brien (2010) considers human geography one of important social sciences that should contribute to a much-needed shift in the discourse on the global environmental change. She sees possibilities of entering a new era for human geography, where geographers are challenged to be leaders in the development of a 'new science on global change' - a science that explores more deeply the human dimensions. Global change research is entering a formative moment and it is important that a human geographic community shapes its interest looking ahead (Castree, 2015).

Artificial Intelligence (AI) has received special attention in recent years from many scientific fields. Since the beginning of the 21 st century, there has been significant progress in Al research. Three factors have contributed to this advancement of Al: big data, novel algorithms, and immense computational power. Many efforts have already been devoted to the integration of geography and $\mathrm{Al}$, and the outcome is a new interdisciplinary area - GeoAl (Janowicz, Gao, McKenzie, Hu, \& Bhaduri, 2020). Rapidly growing field offers many possible directions in the near future. Artificial Intelligence, in cooperation with geographical knowledge, will play a special role in the development of intelligent systems supporting our spatial decision-making processes. The challenge for geographers is not only to import methods from outside disciplines but also export geographic knowledge to other fields. Spatially-explicit Al models can be developed to capture the uniqueness of human geographic problems. There are many aspects of spatial intelligence that are 
expressed e.g. in behavioural geography that can be automated in artificial intelligence. There are also many aspects of $\mathrm{Al}$ that are useful in helping us to explore our own behaviour and human and social phenomena around us (Torrens, 2018).

Over the past two decades, geography has experienced a 'digital turn' a concerted reorientation of focus of attention and approach (Ash, Kitchin, \& Leszczynski, 2018). The digital turn has reshaped how geographical research is conducted and enabled new experience of space, place, mobility, landscape, and the environment. Digital technologies recast economic, social, cultural, political, and other geographies. Technological developments in the area of geographic information systems have created a wide spectrum of possibilities for their application. Gotlib, Iwaniak, and Olszewski (2007) reported e.g. geospatial data infrastructure projects, real estate cadastre, geographical name and border registers, crisis management and early warning systems, flood protection systems, protected area management systems, urban and regional geographic information systems, location and navigation services, systems in agriculture, insurance, waste management, land-use planning, logistics systems, geomarketing systems, transport infrastructure management and monitoring systems, visualization and creation of electronic maps. The challenge is to address the impact of geographic technologies on the decision-making and educational spheres.

Information and communication technologies have opened up ways for collaboration and sharing research data in many new ways. Issues which have been central to the geographical research are now part of the general public consciousness. Many tools and data sets that were formerly used by geographers are now available to the general public. In this context we can observe an emerging concept of open science which can be interpreted as the movement to make scientific research, data and dissemination accessible to all levels of a society. The potential of citizen science is very high, as can be seen from the number of geographical projects using citizen science as a research approach. A significant challenge will be the use of shared geographical knowledge and its adoption in a way that suits local contexts (Trojan, Schade, Lemmens, \& Frantal, 2019).

Human geography is entering an era of big data. Big data sets are characterised by high volume, velocity, variety, exhaustivity, resolution and indexicality, relationality and flexibility. Such data (spatially and temporally referenced) offer many opportunities for human geography analysis enabling rich insights into socio-cultural and spatial understanding of the world. Big data will require contextual or domain-specific knowledge with regard to analysis and interpretation. The challenge of data revolution is a demand for wider appreciation of the variety of emerging data sources and types, and a wider set of skills. Big data pose a number of challenges and raise a number of epistemological, methodological and ethical questions (Kitchin, 2013). At the same time, there is a challenge to guard against marginalisation of small data studies. On the one hand big data generally capture what is openly expressed (e.g. people's actions and behaviours; the movement of things), on the other hand small data studies are stronger not only at capturing emotions, values, opinions and beliefs, but also at understanding the varied, contextual, rational and irrational ways in which people interact. They will require a different set of research tools and they should be much more finely tailored to answering specific human geographical research questions. Despite the urgent need to address data issues in human geography, there is a danger that uncritical preocupation with data can ommit imagination and creativity. Interestingly, Knox (1989) pointed out this danger three decades ago.

Several researches in human geography are marked by the so-called spatial separatism. Although reality has three dimensions (space, time and matter), geography according to the spatial separatist view is the science of the first. Sack (1972) pointed out 
that space, time and matter cannot be separated analytically in an empirical science. One of the interesting challenges for human geography is to apply the knowledge from the time-geography concerning couplings in time and space (Ellegård, 2018).

Posthumanism shows ways in which it is possible to connect human and non human, perceptive and non-perceptive aspects of the world in the search for bridging the dualism between physical and human geography. Indeed, it is no longer easy to determine whether a scientist practicing actor network theory or hybrid geography is a physical or human geographer. This division loses its meaning in this world. Apparently we are returning to the world as understood by Humboldt and Ritter, in which nature and culture formed an inseparable and imposingly diversified unity (Cresswell, 2013: 259). In posthumanist geography, a shift towards the adaptation of transhumanism concepts and a gradual transition to transhumanist geography can be expected, which may respond adequately to the onset of the post-information age.

Current syntheses of geographic views of economic wealth, poverty, human development and the environment demonstrate that the North-South boundary of international development is increasingly untenable. The significant spatial shift in the inequalities, both between and within countries, regions and North and South, should play a central role in geographic development studies (Horner \& Hulme, 2017). The challenge for scholars in human geography is to understand and work towards addressing new aspects of the 21 st century global development divides.

The global health crises are usually accompanied by political, economic, and social crises that deepen the existing inequalities and disproportionately affect the most vulnerable segments of society. The global pandemics also have very significant geographical consequences. There will be an urgent need for geographers and a wide range of other scholars to critically examine their fallout (Rose-Redwood et al., 2020). The challenge for human geography is to highlight the diverse theoretical perspectives and methodological approaches and offer an explanation of the specificities of geographical differentiation of global health crises. The urgency of the challenge is confirmed by the current spread of the novel coronavirus (Covid-19) that has resulted in the most devastating global public health crisis in over a century.

The continuing tradition of critical geography will probably persistently seek bridges between the new alternatives of social order and the majoritarian capitalist society. In terms of geography, concepts emphasizing the autonomy of local and regional communities (several types of regionalism - important site for the investigation of the contemporary social change, glocalization, complex territorial approach, local economy, local currencies, local technologies, etc.) are and will be particularly attractive.

The spatio-temporal processes of migrations cause the continual reshaping of places as people move between various localities of origin and destination. Human geography is especially interested in these processes because of the spatial linkages and interconnections that are formed when people move. The numbers of flows and channels resulting from migration have risen dramatically in the past decade and cause significant transformation both of sending and receiving areas. Many causes and consequences of migration create complicated mutually interrelated political, economic, social, cultural, and demographic effects, all of which are studied by human geography. Because of the changes in personal and social mobility associated with globalization it is ever harder to distinguish migration from the greater register of flows. Recent research focuses on the impact of climate change, the migration-development nexus, and the heightened security and surveillance. The important challenge for human geographers is to explore the multiple negative and positive consequences of migration for sending and receiving localities, regions and their societies, as well as for migrants themselves. 


\section{Some reflections on the direction of human geography among geographical communities of the Visegrad countries}

Geographies in V4 countries share common roots taken over from the German geographical school. In interwar period, it was also influenced by the French geographical thought inspired by the Vidalian regional geography. After the WWII, communities of geographers also experienced the influences of the Soviet geographical school which has fairly limited human geography by its ideological indoctrination and restricted contacts with the Western geography. On the other side though, in this situation human geographers could treat the applied themes first of all in the sphere of strategic, regional and territorial planning. Their cooperation, in the frame of the COMECON countries, also thrived. Some currents of the Anglo-Saxon geography which did not jeopardize the ideology were reflected too. Systemic approach and development of geography as spatial science, especially application of quantitative methods and modelling, is one example. After the break-through in the 1980s, new opportunities opened up for the Czech, Hungarian, Polish and Slovak geographers consisting of broader contacts with the world geography and in the relation to the new themes, epistemological fields and methodological approaches of research. In terms of sources of inspiration Anglo-American geography prevailed as a natural consequence of its world hegemony (Bajerski, 2010). In the last decades, discussions in geographical communities in these countries were comparatively varied as far as their themes are concerned. Let us draw attention to some of them.

In the last decade of the 20th century and the first decade of the new millennium, human geography in the four national geographical communities concentrated mainly on the study of the process and effects of the social, political and economic transformation. The beginning of the new millennium became a strong incentive for an effort to inventorying the results of geographical research, reflection on the status of geography in individual countries in the context of its world development and an effort to scheme the possibilities of its further development (for instance (Chojnicki, 2004; Liszewski, 2004; Łoboda, 2004; Matlovič \& Ira, 2006; Hampl, Dostál \& Drbohlav 2007; Matlovič, 2007a; Timár, 2007; Ira \& Lacika, 2009; Hampl, Dostál \& Drbohlav 2007; Matoušek, Vogt, Ženka, 2011).

New impulses often accompany the arrival of new generations of geographers. In an effort to establish themselves they try to demonstrate how they differ from their predecessors and aspire to bring innovatory research themes, approaches, methods or techniques. There is an interesting example in the Czech geography. The generation that followed after the 1989 social change expressed itself by a publication with the primary aim to explain the modern western geographical thought to the Czech (Czechoslovak) professional public, as it lost contacts with it in the years of isolation during the period of real socialism. Another aim was to reflect on the trend opening the geography to other social sciences (sometimes referred to as the social turn in geography or the post-positivist turn) - Sýkora (1993). The discourse of the generation of Czech geographers which appeared on the turn of the first and the second decades of the 21st century is the publication which emphasises the cultural turn in geography and a spatial turn in humanities while the category of space is conceptualized from the social-constructivist position (Matoušek \& Osman, 2014). The polemics between the representatives of the younger generation of Czech geographers that appeared in journal Informace ČGS (Kopeček, Drobik, \& Hasalová, 2011; Matoušek et al., 2011; Osman, Trávníček, Trojan, \& Konečný, 2011; Kofroň 2012, 2013; Matoušek, 2013) is another example. The core of the polemics was the controversy between Kofron (2012, 2013) and Matoušek (2013) concerning the 
plurality of epistemological approaches. Kofroň based on neo-positivism and scientific realism criticised the theoretical and methodological impotence of fragmented geography and proposed the remedy using the multipolarity of separated epistemological approaches. Hynek (2008) is member of older generation of Czech geographers which profess post-structuralism. Inter-generation disputes in Polish generation were discussed by Plit (2013). Recently there took place an interesting discussion of members of various generations of Polish geography about the status, perspectives and strategies of development of human geography (Suliborski, 2016).

Older generation of geographers maintains distance from critical geography influenced by Marxism and neo-Marxism. Their negative experience with the ideological indoctrination of human geography in the period of real socialism explains this attitude. This period of "Sovietisation" of geography has been best mapped in Hungary thanks to works of Györi and Gyuris (2012) and by the critical reflection of Ginelli (2018). Several members of younger generation are more open in relation to critical geography. However, Lisocka-Jaegermann (2016) reports that critical geography is not sufficiently developed in Polish geography. Matlovič and Matlovičová (2020) arrived at a similar conclusion in relation to the Slovak geography. Other currents of geographical thought associated with critical geography also face troubles. For instance, feminist geography (Timár \& Fekete, 2010), Ginelli (not dated citation) summarised the situation of critical geography in Hungary while his study also applies to other geographical schools. After 1989, human geography positivist and important Hungarian geographers either ignored or undervalued the feminist, structuralist, post-structuralist, Marxist, postmodern or post-colonial approaches and pushed out of the scientific regime as a fad. Situation is better in Czech geography where several young researchers develop critical geography (Osman \& Matoušek, 2014).
The question of the position of human geography in a wider context of autonomy, identity and unity of geography became the theme of discussion (Liszewski, 2004). Bański (2010) criticized the deteriorating position of Polish geography compared to other sciences first of all in the consequence of the continuing sterile discussion about unity of geography. Other authors pointed to the fact that the contemporary Polish geography is rather multidisciplinary than interdisciplinary and transdisciplinary and the function of synthesising science is only slightly evident (Kostrzewski, Roo-Zielińska, Krzemień, \& Lisowski, 2015: 45). Several authors supported the idea of reintegration of geography (for example, Lisowski, 2012; Jackowski, 2015; Wilczyński, 2011a), and some of them believe that it is necessary to return to the legacy of the Polish geographical thought (Wilczyński, 2011b). In Slovakia it was Ira, Michálek, and Podolák, (2005) and Matlovič $(2006,2007 b)$ who argued in favour of integrated geography. Ira et al. (2005) see certain potential in exploitation of sustainability concept, Matlovič (2006, 2007b) mentions regional geography and exploitation of the concept of place in its trinity version. Other way of solution to integrated geographical research in Slovakia is seen in the use of incentives of critical physical geography (Otahel', Matlovič, Matlovičová, Michaeli, \& Vilček, 2019).

In this respect, there is an increased effort of Central European geographers to study the development of geographical thought and reflection of currents of world geography in individual national geographical schools. In Hungary it was Dövényi and Hajdú (2000) and Gyimesi (2011). The most influential in the Czech geographical community are the schools of Prague (Albertian) and Brno The representative of the Brno school Hynek (2008) drew attention to the need to move the focus from theoretical geography to geographical thought which also led to the origin of the first text book of geographical thought (Daněk, 2013). Wilczyński (2009, 2011a) in Polish geography advises about the 
necessity to study geographical thought and he processed a monograph about the sources of ideas and autonomy of geography. Matlovič and Matlovičová (2015) in Slovakia prepared the first text book of geographical thought and elaborated the issue of discontinuities in the world geographical thought (Matlovič \& Matlovičová, 2020).

Distinguished representative of older generation of Polish geographers, Maik (2016a) summed up the greatest risks for the future of Polish human geography including fragmentation, disintegration and identity crisis of the scientific discipline, absence of strategy for the development, methodological weakness, and increasing intellectual dependence on American geography, insufficient quality and level of the master and PhD studies at universities. In his another study Maik (2016b) tries to find answer the question which philosophical and methodological approaches are most promising from the point of view of future of human geography. In his opinion solutions to present problems should be sought in a new type of thought. Without providing a clear answer he points to the need to return to sources of geographical traditions seeing certain potential in rational methodological eclecticism, that is, critical and systematic application of complementary from different sources.

\section{Conclusion}

Contemporary human geography refers to a type of academic activity, which encompasses a diversity of ways of examining the presence and actions of humans in geographical space. Human geography can be expected to retain the nature of a hybrid formation in which multiple paradigmatic viewpoints (without mono-paradigm dominance - see e.g. Johnston \& Sidaway, 2016: 399) coexist within the same institutional and (sub) disciplinary spaces. The maintenance of the human geography as discrete and internally coherent will not be straightforward. The evolution of human geography in recent decades shows that there is a constant change. Despite complex and often complicated developments in human geographic thought and practice, we believe that the intellectual richness of human geography and its diversity make it a prerequisite for a creative search for future direction and responses to many challenges (Ira \& Matlovič, 2019).

Human geography in the geographical communities of theVisegrad Four concentrated in the last thirty years mainly on the study of the process and effects of the social, political and economic transformation. The beginning of the new millennium is characterized by an effort to inventory the results of geographical research, reflection on the status of geography in individual countries in the context of its developments in countries successful in geographic research and an effort to scheme the possibilities of its further development. New impulses often accompany the arrival of new generations of geographers sometimes influenced by the development of Western geographical thought.

There is a presumption that human geography will continue to practice engaged pluralism resulting from its paradigmatic diversity (Castree \& Gregory, 2012). It can be expected in the future that human geography will continue to make important contributions to thought and the search for practical solution in organizing time-space activities of individuals and society. Several inspirations will surely draw on nearby humanities, social and environmental sciences while enriching and inspiring them.

Debate about how geography should be practised and thought will reflect not only internal impulses but also external impacts of the changing world (changing population, economy, technology, built and natural environments, changing efficiency, availability and sustainable use of natural resources as well as the changing interaction with the environment) and trends in the wider academic milieu to which geographers belong. Human geography tends to import part of its ideas and trends from wider academic milieu and societies, to which human geographers 
belong, and thus, the intersections of new approaches, ideas and generational cycles in research trends and their recombinations can result in a rapid (and in some cases unexpected) shift of focus of human geography.

\section{Acknowledgement}

This work was supported by the Scientific Grant Agency VEGA (grant number 1/0049/18).

\section{References}

Ash, J., Kitchin, R., Leszczynski, A. (2018). Digital turn, digital geographies? Progress in Human Geography, 42(1), 25-43. https://doi.org/10.1177\%2F0309132516664800

Bajerski, A. (2010). Anglo-amerykańska dominacja w geografii: główne wątki dyskusji prowadzonej w ramach geografii krytycznej. Przegląd Geograficzny, 82(2), 143-158. https://doi.org/10.7163/przg.2010.2.1

Bański, J. (2010). Stan krytyczny polskiej geografi i - krytyka stanu. Przeglad Geograficzny, 82(3), 319-33. https://doi.org/10.7163/przg.2010.3.1

Bański, J. (2013). Jaka geografia? - uwarunkowania i spojrzenie w przyszłość. Przegłąd Geograficzny, 85(2), 291-307. https://doi.org/10.7163/przg.2013.2.7

Castree, N. (2015). Changing the Anthropo(s)cene: Geographers, global environmental change and the politics of knowledge. Dialogues in Human Geography, 5(3), 301-316. https://doi.org/10.1177/2043820615613216

Castree, N., Gregory, D., (Eds). (2012). Human geography. Vol. I. London: SAGE. https://doi.org/10.4135/9781446261965

Chojnicki, Z., (Ed.). (2004). Geografia wobec problemów teraźniejszości i przyszłości, Poznań: Bogucki Wydawnictwo Naukowe.

Cresswell, T. (2013). Geographic Thought. A Critical Introduction. Oxford: Willey-Blackwell.

Crutzen, P.J., Stoermer, E.F. (2000). The Anthropocene. IGHP Global Change Newsletter, 41, 17-18.

Daněk, P. (2013). Geografické myšlení: úvod do teoretických př́stupů. Brno: Masarykova univerzita.

Dövényi, Z., Hajdú, Z. (2000). Evolution of human geographical thought in Hungary in the 20th century." In Z. Kovács, ed., Hungary towards the twenty-first century: The human geography of transition (pp. 29-48), Budapest: Geographical Research Institute, HAS.

Drulák, P. (2009). Synteza teorií cestou jejich desktrukce. In P. Barša et al., Dialog teorií. (pp. 225-245). Praha: Slon.

Ellegård, K. (2018): Thinking Time Geography: Concept, Methods and Applications. London: Routledge. https://doi.org/10.4324/9780203701386

Ginelli, Z. (n.d.). Hungarian Human Geography since 1945. Retrieved from https://www.academia.edu/35001378/Hungarian_Human_Geography_since_1945_draft_docx

Ginelli, Z. (2018). Critical remarks on the "sovietization" of Hungarian human geography. In Hîncu, A. Karady, V. (eds.), Social sciences in the other Europe since 1945 (pp. 50-89), Budapest: Center for Historical Studies, Central European University.

Gotlib, D., Iwaniak, A., Olszewski, R. (2007). GIS. Obszary zastosowania. Warszawa: PWN.

Graves, N.J. (1981). Can geographical studies be subsumed under one paradigm or are a plurality of paradigms inevitable? Terra, 93(3), 85-90.

Gyimesi, Z. (2011). Thomas S. Kuhn gondolatainak szerepe a földrajztudo-mány történetének kontextualista elbeszélésében. Tér és Társadalom, 25(1), 81-99. https://doi.org/10.17649/TET.25.1.1774 
Győri, R., Gyuris, F. (2012). The sovietisation of Hungarian geography. Mitteilungen der Österreichischen Geographischen Gesellschaft, 154, 107-128. https://doi.org/10.1553/moegg154s107

Hampl, M., Dostál, P., Drbohlav, D. (2007). Social and cultural geography in the Czech Republic: under pressures of globalization and post-totalitarian transformation. Social \& Cultural Geography, 8(3), 475-493. https://doi.org/10.1080/14649360701489029

Holt-Jensen, A. (2018). Geography history and concepts, Fifth edition. London: SAGE.

Horner, R., Hulme, D. (2017). Converging divergence? Unpacking the new geography of 21st century global development. GDI Working Paper 2017-010. Manchester: The University of Manchester. http://hummedia.manchester.ac.uk/institutes/gdi/publications/workingpapers/GDI/GDI_WP2017010_Horner_Hulme.pdf

Hubbard, Ph., Kitchin, R., Bartley, B. Fuller, D. (2002). Thinking geographically. New York: Continuum.

Hynek, A. (2008). Geographium. Miscellanea Geographica: Universitatis Bohemiae Occidentalis, 14, 39-45.

Ira, V., Michálek, A., Podolák, P. (2005). Humánna geografia v Geografickom ústave SAV v období transformácie spoločnosti v SR. Geografický časopis, 57(4), 327-343.

Ira, V., Lacika, J., (Eds.). (2009). Slovak geography at the beginnig of the 21st century. Geogaphia Slovaca, 26, Bratislava: Geografický ústav SAV.

Ira, V., Matlovič, R. (2019). Wyzwania dla przyszłych kierunków rozwoju geografii człowieka. In Wiśniewski, R., Regulska, E. (Eds.), /Tradycja i współczesność geografii w Polsce/ (pp. 77-84). Warszawa: Instytut Geografii i Przestrzennego Zagospodarowania im. S. Leszczyckiego PAN.

Jackowski, A. (2015). Czy geografia pozostanie geografia? Rozważania na czasie. Czasopismo Geograficzne, 86(1-2), 3-21.

Janowicz, K., Gao, S., McKenzie, G., Hu, Y., Bhaduri, B. (2020). GeoAl: spatially explicit artificial intelligence techniques for geographic knowledge discovery and beyond. International Journal of Geographical Information Science, 34(4), 625-636, https://doi.org/10.1080/13658816.2019.1684500

Johnston, R., Sidaway, J.D. (2016). Geography and geographers. Anglo-American human geography since 1945. 7th Edition. London: Routledge. https://doi.org/10.4324/9780203523056

Kitchin, R. (2013). Big data and human geography: Opportunities, challenges and risks. Dialogues in Human Geography, 3(3), 262-267. https://doi.org/10.1177/2043820613513388

Kofroň, J. (2012). Geografie fragmentovaná jako geografie úspěšná? Postmoderní sen noci ostravské. Informace ČGS, 31(1), 1-10.

Kofroň, J. (2013): Inkluzivní sny v exkluzivní realitě. Informace ČGS, 32(2), 34-43.

Kopeček, V., Drobik, T., Hasalová, J. (2011). Česká geografie ve 21. století: Skutečně pro život? Informace ČGS, 30(2), 25-29.

Kostrzewski, A., Roo-Zielińska, E., Krzemień, K., Lisowski, A. (2015). Geografia w okresie transformacji systemu nauki w Polsce - aktualny stan, perspektywy rozwoju. Czasopismo Geograficzne, 86(1-2), 23-47.

Kuhn, T.S. (1997). Struktura vědeckých revolucí. Praha: Oikonmenh.

Lisocka-Jaegermann, B. (2016). Geografia wobec krytycznej teorii społecznej: doświadczenia i perspektywy. Czy w Polsce potrzebujemy geografii krytycznej?. In W. Maik., A. Suliborski, M. Wójcik (Eds.), Nowe i stare perspektywy i ujęcia w geografii na przełomie XX i XXI wieku, (pp. 141-158), Podstawowe idee i koncepcje w geografii (vol. 9), Łódź: Wydawnictwo Uniwersytetu Łódzkiego.

Lisowski, A. (2012). O miejscu geografii społeczno-ekonomicznej w geografii i systemie nauki. Przeglad Geograficzny, 84(2), 171-195. https://doi.org/10.7163/przg.2012.2.1

Liszewski, S. (2004). Stan dyskusji polskich geografów na temat jedności i zakresu pojęciowego współczesnej geografii (na poczq̨tku XXI wieku). In A. Jackowski (Ed.), Geografia u progu XXI wieku (pp. 11-26). Kraków: Instytut Geografii Gospodarki Przestrzennej Uniwersytetu Jagiellońskiego.

Liszewski, S., Suliborski, A. (2006). Jedność geografii a problem kształcenia akademickiego. Czasopismo Geograficzne, 77(1-2), 3-22. 
Łoboda, J. (2004). Polská geografie na prahu nového milénia. Geografie, 109(4), 314-327.

Maddrell, A. (2009). History of Geography. In R. Kitchin, N. Thrift (Eds.), International Encyclopedia of Human Geography (pp. 415-428), Oxford: Elsevier.

Maik, W. (2016a). Geografia człowieka - tożsamość dyscypliny oraz jej stan i perspektywy rozwojowe w Polsce. In A. Suliborski (Ed.), Stan, perspektywy i strategia rozwoju geografii społeczno-ekonomicznej w najbliższych latach (do 2030 r.). Dyskusja międzypokoleniowa (pp. 27-46), Łódź: Wydawnictwo Uniwersytetu Łódzkiego.

Maik, W. (2016b). Jaka jesteś i dokąd zmierzasz geografio człowieka. In W. Maik, A. Suliborski, M. Wójcik (eds.), Nowe i stare perspektywy oraz ujęcia w geografii na przełomie XX i XXI wieku (pp. 79-102), Podstawowe idee i koncepcje w geografii (vol. 9), Łódź: Wydawnictwo Uniwersytetu Łódzkiego.

Matlovič, R. (2006). Geografia - hladanie tmelu (k otázke autonómie a jednoty geografie, jej externej pozície a inštitucionálneho začlenenia so zretelom na slovenskú situáciu). Folia Geographica, 44(9), 6-43.

Matlovič, R. (2007a). Slovak geography at the beginning of 21st century. In M. Strzyż, (Ed.), Geography Science in the Regional Studies. Vol. 5 (pp. 45-64). Kielce: AŚ, PTG.

Matlovič, R. (2007b). Hybridná idiograficko-nomotetická povaha geografie a koncept miesta s dôrazom na humánnu geografiu. Geografický časopis, 59(1), 3-23.

Matlovič, R., Ira, V. (Eds.). (2006). Vývoj, súčasný stav a perspektívy slovenskej geografie v 21. storočí. Folia Geographica, 9, Prešov: University of Prešov.

Matlovič, R., Matlovičová, K. (2012). Spoločenská relevancia a budovanie značky geografie. Geografie - The Czech Journal of Geography, 117(1), 33-51.

Matlovič, R., Matlovičová, K. (2015). Geografické myslenie. Prešov: Prešovská univerzita, Fakulta humanitných a prírodných vied.

Matlovič, R., Matlovičová, K. (2020). First and second order discontinuities in world geographical thought and their primary reception in Slovak geography. Folia Geographica, 62(1), 52-76.

Matlovič, R., Matlovičová, K., Nemethyová, B. (2012). Academic institutionalisation and social relevance of geography. In H. Svobodová (Ed.), Proceedings of 19th International Conference Geography and Geoinformatics: Challenge for Practise and Education. (pp. 50-60), Brno: Muni press, Masarykova univerzita.

Matoušek, R. (2013). Jaké metody pro jakou geografii? K př́nosu geografie a inspiraci z jiných disciplín. Informace ČGS, 32(1), 16-24.

Matoušek, R., Vogt, D., Ženka, J. (2011). Výzvy české geografie: Od „Černé knihy“ ke světlým zítřkům. Informace ČGS, 30(2), 8-17.

Matoušek, R., Osman, R., (Eds.). (2014). Prostor(y) geografie. Praha: Karolinum.

Mayer-Schönberger, V., Cukier, K. (2014). Big data. Revoluce, ktorá změní způsob, jak žijeme, pracujeme a myslíme. Brno: Computer Press.

Nayak, A., Jeffrey, A. (2011). Geographical thought. An introduction to ideas in Human Geography. Harlow: Pearson Education.

O'Brien, K. (2010). Responding to environmental change: A new age for human geography? Progress in Human Geography, 35(4), 542-549.

Osman, R., Trávníček, J., Trojan, J., Konečný, O. (2011). K čemu doktorandi? Pokračování diskuze XXII. sjezdu České geografické společnosti v Ostravě. Informace ČGS, 30(2), 18-24.

Otahel', J., Matlovič, R., Matlovičová, K., Michaeli, E., Vilček, J. (2019). Critical approaches, integration of research and relevance of geography. Geografický časopis, 71(4), 341-361.

https://doi.org/10.31577/geogrcas.2019.71.4.18

Pattison, F. (1964). The four traditions of Geography. The Journal of Geography, 63(5), 211-216.

Plit, F. (2013). O sporze pokoleniowym w polskiej geografii i jego uwarunkowaniach. Przeglad Geograficzny, 85(4), 655-675. https://doi.org/10.7163/PrzG.2013.4.7 
Rose-Redwood, R., Kitchin, R., Apostolopoulou, E., Rickards, L., Blackman, T., Crampton, J., Rossi, U., Buckley, M. (2020). Geographies of the COVID-19 pandemic. Dialogues in Human Geography, 10 (2), 97-106. https://doi.org/10.1177/2043820620936050

Sack, R.D. (1972). Geography, geometry, and explanation. Annals of the Association of American Geographers, 62(1), 61-78. https://doi.org/10.1111/j.1467-8306.1972.tb00844.x

Sýkora, L. (Ed.). (1993). Teoretické př̌stupy a vybrané problémy v současné geografii. Praha: Přírodovědecká fakulta Univerzity Karlovy.

Špelda, D. (2009). Proměny historiografie vědy. Praha: Filozofia.

Timár, J. (2006). The transformation of social and cultural geography during the transition period (1989 to present time) in Hungary. Social \& Cultural Geography, 7(4), 649-667. https://doi.org/10.1080/14649360600825760

Timár, J., Fekete, E. (2010). Fighting for recognition: Feminist Geography in East-Central Europe. Gender Place and Culture, 17(6), 775-790.

Torrens, P.M. (2018). Artificial intelligence and behavioral geography. In D.R. Montello (Ed.), Handbook of behavioral and cognitive geography (pp. 357-371). Cheltenham and Northampton: Edward Elgar Publishing. https://doi.org/10.4337/9781784717544.00031

Trojan, J., Schade, S., Lemmens, R., Frantal, B. (2019). Citizen science as a new approach in Geography and beyond: Review and reflections. Moravian Geographical Reports, 27(4), 254-264. https://doi.org/10.2478/mgr-2019-0020

Wilczyński, W. (2009). On the necessity of the history of geographical thought. Bulletin of Geography, Socio-economic Series, 11, 5-14. http://dx.doi.org/10.2478/v10089-008-0017-3

Wilczyński, W. (2011a). Kontrowersje wokół jedności i tożsamości geografii. Przestrzeń Społeczna, 1(1), 1-9.

Wilczyński, W. (2011b). Co zostało z idei jedności geografii? Annales Universitatis Paedagogicae Cracoviensis, Folia 105, Studia Geographica, 2, 135-146.

Wilczyński, W. (2011). Ideowe źródła i tożsamość geografii. Kraków: Wydawnictwo Uniwersytetu Pedagogicznego. 
